\title{
Quality Aspects for High Nutritional Value Pretzel
}

\author{
Sahar S. El-Gohery \\ Bread and Pasta Dept., Food Technology Research Institute, Agricultural Research Center, Giza, \\ Egypt
}

Received: 20 August 2020 / Accepted 10 Oct. 2020 / Publication date: 20 Oct. 2020

\begin{abstract}
The present study was carried out to improve the nutritional value of pretzels made from wheat or barely flour by adding chickpea or sweet lupine powder at different percent of replacement. Chemical composition of raw materials indicated that sweet lupine and chickpea powder contained higher amounts of protein, fat and crude fiber $(28.45,26.05 \% \& 7.53,8.08 \% \& 7.57,4.86 \%$, respectively) compared with wheat and barley flour. Wheat and barley pretzels replaced by $40 \%$ chickpea powder or $20 \%$ sweet lupine powder indicated significant $(P \leq 0.05)$ improvement in different sensory characteristics. Control barley pretzel had higher total essential amino acids content $(41.86 \mathrm{~g} / 100 \mathrm{gm}$ protein), followed by barley pretzel replaced by $20 \%$ sweet lupine powder ( $41.25 \mathrm{~g} / 100$ gm protein). The protein quality indicated increase of biological value (BV) and protein efficiency ratio (PER) for pretzel replaced wheat or barley flour by chickpea or sweet lupine powder. All pretzel samples replaced wheat or barley flour by chickpea or sweet lupine powder had higher content of minerals than control samples. Barley pretzel samples had higher content of magnesium, potassium, calcium, iron and zinc compared with wheat pretzel samples. Wheat and barley pretzel samples replaced by chickpea or sweet lupine caused an increase of total phenolic and total flavonoids contents. Antioxidant activity (DPPH\%) showed that barley pretzels had the highest antioxidant activity, while wheat pretzels showed the lowest activity.
\end{abstract}

Keywords: Pretzel, Wheat \& barely flour, chickpea and sweet lupine, protein quality, sensory characteristic, antioxidant activity.

\section{Introduction}

Pretzels are popular snack food. The production and consumption of pretzel are increasing at a fast rate because consumers want alternatives to fried snack foods. At present, pretzel production is fully automized in the developed countries to meet the rising consumer demands and aspirations (Seetharaman et al., 2004; Sekhon, 2014).

Pretzel could be produced by the simple process and a few ingredients including flour, oil, sugar, and yeast. During pretzel processing, the dough is shaped by an extruder at relatively low pressures, treated with hot-alkali solution, salted, and baked. The baking process is carried out in two stages i.e.: a quick rapid initial bake at high temperature, followed by a slow drying process at a lower temperature (Groff, 2001). Most of the available snacks (such as pretzel) are made from refined cereal flours that are rich in salts, saturated fats, and easily digested carbohydrates. It may be argued that the increase in the consumption of snack food products has led to an increase in obesity and thus an unhealthy population (Brennan et al., 2013; Struck et al., 2014; Oliveira et al., 2015).

The health benefits of the wheat flour can be further enhanced by blending with the flours of other nutritious grains. People have become more health-conscious and now look for additional health benefits besides basic nutrition from cereal-based food products. For this reason, more and more multigrain food products are available in the market and attracting more consumers $\left(\mathrm{O}^{\prime \prime}\right.$ tles and Cagindi, 2006).

Wheat (Triticum aestivum L.) bread is nutritionally poor in lysine and the supplementation of wheat flour with high protein- content flours is a powerful tool to improve the nutritional quality of bakery products (Sabanis and Tzia, 2009; Shahine-Fatma et al., 2013; Hanaa et al., 2018). Proteinenriched food from plant sources is rich in lysine, a limiting amino acid in wheat flour (Day, 2013; Chardigny and Walrand, 2016).

Corresponding Author: Sahar S. El-Gohery, Bread and Pasta Dept., Food Technology Research Institute, Agricultural Research Center, Giza, Egypt

E-mail: sahar_elgohery@hotmail.com 
Barley (Hordeum Vulgare) is one of the most important winter cereal crops. It's grown over a wide range of soil variability (saline and poor) and under many diverse climate conditions as well as water shortage compared with other grains crops. Barley is a storehouse of nutrients but its direct use as food is very limited, but it can be easily blended with other flours to make healthy blended products. Adding barley to wheat chapatti and biscuit can considerably enhance the nutritional value of these products in terms of high antioxidant activity, phenolic content, and $\beta$-glucan content (Narwal et al., 2017; Ahmed and Hassan, 2019).

Legumes are very important for human consumption due to its high protein content. Due to its technological properties, their use has been carried out not only by consumption of whole grains, but also by its incorporation into products as flours, concentrates, or isolates, to improve the stability, texture, and nutritional aspect of preparations. The benefit of producing cereal-legume composite foods may be considered as twofold: (1) There is an overall increase in the protein content of the composite food compared to when only the cereal forms the base, and (2) there are better amino acids balance due to the contribution of lysine by legumes and the contribution of methionine by cereals (Makri et al., 2005; Hanaa et al., 2018).

Worldwide, chickpeas received attention because of their physiological benefits. Extensive efforts have been conducted to increase the intake of these grain legumes by integrating them as flours into food products: bread (Hefnawy et al., 2012; Zafar et al., 2013), spaghetti (Arab et al., 2010), cakes (Gómez et al., 2008), and even biscuits (Yadav et al., 2012). In Egypt, chickpea seed usually consumed in different ways, seeds used in several dishes and flour supplements in weaning food mixes, bread, and biscuit (Faris and Takruri,2002; Mansour, 2007).

Lupine is widely used in food production particularly as a valuable and technologically desirable additive mainly in bakery products as well as in dietary and functional food products (Loza and Lampart Szczapa, 2008). Lupin flour has a high potential of a "nonintrusive" ingredient that can be substituted or used as an alternative in foods such as cereal products because lupin flour is pale in color and low in odor and flavor (Clark and Johnson, 2002). A combination of lupine and wheat flour can also help improve the amino acid profile of the product. Wheat flour proteins which are poor in lysine and relatively higher in the sulphur-containing amino acids (methionine and cysteine) can be complemented by the amino acids found in lupin protein which are high in lysine and low in sulphurrich amino acids (Rayas-Duarte et al. 1996; Mann and Truswell, 2002).

Turmeric (Curcuma longa) has been used traditionally as an antidiabetic and has been proven scientifically to posse high antioxidant activity and anticancer properties. The active components in turmeric, such as curcumin, which is a yellow coloring agent, present in the rhizomes of turmeric, and tetrahydro-curcumin (THC), which is the major colorless metabolites of curcumin, also possess antidiabetic, anti-inflammatory, and antioxidant activity. In the scientific literature, a large amount of information is available regarding the nutritional properties of turmeric and its use to develop sweet bakery products (Olatunde-Farombi et al., 2008; Braga et al., 2003; Jayaprakasha et al., 2005; Singh et al., 2010; Lim et al., 2011).

Accordingly, this study aimed to improve the nutritional value of pretzels made from wheat flour, barley flour, chickpea powder, and sweet lupine powder at a different percent of replacement, in addition to adding turmeric for all blends to obtain a pretzel with good nutritional and quality characteristics.

\section{Materials and Methods}

\section{Materials}

Wheat flour of $72 \%$ extraction rate was obtained from South Cairo Mills Company, Giza, Egypt. Naked barley (Hordeum vulgare L.) variety Giza 130 was obtained from Barely Research Department, Field Crops Research Institute, Agriculture Research Center, Giza, Egypt.

Chickpea seeds (Cicer arietinum L.), Sweet lupine seeds (Lupinus albus L.), Turmeric powder (Curcuma longa), corn oil, sugar, yeast, salt and milk powder were purchased from the local market, Giza, Egypt. 


\section{Methods}

\subsection{Preparation of barley flour, chickpea, and Sweet lupine powder}

Barley, chickpea, and sweet lupine seeds were cleaned to remove stones, dust, and undesirable materials, then seeds were milled and sieved to give flour or powder of $250 \mu \mathrm{m}$ by using Brabender ${ }^{\circledR}$ Duisburg Mill, Type 27002 Germany.

\subsection{Pretzel Preparation}

Pretzel samples were prepared according to the method described by Seetharaman et al. (2004) using wheat flour $72 \%$ (control A) and Barley flour (control B) and different replacements which recorded in Table (1). The dry ingredients were mixed for $1 \mathrm{~min}$ in a lab mixer, then water was added as required for each sample, and the mixture was further mixed for $4 \mathrm{~min}$ to form the dough. The resulting dough was allowed to rest for $20 \mathrm{~min}$ before shaping. The shaped pretzel was baked at 180 $\mathrm{C}^{\circ}$ for $10 \mathrm{~min}$, then sprayed with a caustic solution (1\% sodium hydroxide). Finally, the produced pretzels were baked at $93 \mathrm{C}^{\circ} / 30 \mathrm{~min}$.

\subsection{Analytical Methods}

Moisture, protein, fat, crude fiber, and ash of raw materials and the produced pretzel were determined according to the AOAC (2012). Total carbohydrates was calculated by difference. The energy was calculated from the following equation:

$$
\text { Energy }(\mathrm{Kcal} / 100 \mathrm{~g})=(\% \text { Total carbohydrates } \times 4)+(\% \text { protein } \times 4)+(\% \text { fat } \times 9) . .(1)
$$

Magnesium $(\mathrm{Mg})$, sodium $(\mathrm{Na})$, potassium $(\mathrm{K})$, calcium $(\mathrm{Ca})$, iron $(\mathrm{Fe})$, phosphorus $(\mathrm{P})$ and zinc $(\mathrm{Zn})$ were determined by using the atomic absorption spectrophotometer (Perkin-Elmer model 3300) as described by Kirleis et al. (1984).

Table 1: The ingredients of pretzel formula

\begin{tabular}{|c|c|c|c|c|c|c|c|c|c|c|}
\hline Sample & $\begin{array}{c}\text { Control } \\
\text { (A) }\end{array}$ & $\begin{array}{c}\text { No. } \\
2\end{array}$ & $\begin{array}{c}\text { No. } \\
\mathbf{3}\end{array}$ & $\begin{array}{c}\text { No. } \\
4\end{array}$ & $\begin{array}{c}\text { No. } \\
5\end{array}$ & $\begin{array}{c}\text { Control } \\
\text { (B) }\end{array}$ & $\begin{array}{c}\text { No. } \\
7\end{array}$ & $\begin{array}{c}\text { No. } \\
8\end{array}$ & $\begin{array}{c}\text { No. } \\
9\end{array}$ & $\begin{array}{r}\text { No. } \\
10\end{array}$ \\
\hline Wheat flour (g) & 100 & 80 & 60 & 80 & 60 & $\begin{array}{l}---- \\
\end{array}$ & ----- & ----- & ----- & ---- \\
\hline Barley flour (g) & ----- & ----- & ----- & ----- & ----- & 100 & 80 & 60 & 80 & 60 \\
\hline Chickpea powder(g) & ----- & 20 & 40 & ----- & ----- & ----- & 20 & 40 & ----- & ---- \\
\hline Sweet lupine powder (g) & ----- & ----- & ----- & 20 & 40 & ----- & ----- & ----- & 20 & 40 \\
\hline Turmeric powder (g) & ----- & 5 & 5 & 5 & 5 & ----- & 5 & 5 & 5 & 5 \\
\hline Oil (g) & 20 & 20 & 20 & 20 & 20 & 20 & 20 & 20 & 20 & 20 \\
\hline Sugar (g) & 1 & 1 & 1 & 1 & 1 & 1 & 1 & 1 & 1 & 1 \\
\hline Yeast (g) & 1 & 1 & 1 & 1 & 1 & 1 & 1 & 1 & 1 & 1 \\
\hline Salt (g) & 1 & 1 & 1 & 1 & 1 & 1 & 1 & 1 & 1 & 1 \\
\hline Milk powder (g) & 4 & 4 & 4 & 4 & 4 & 4 & 4 & 4 & 4 & 4 \\
\hline Water (ml) & 49 & 56 & 62.5 & 60 & 65 & 98 & 85 & 75 & 82 & 78 \\
\hline
\end{tabular}

\subsection{Sensory evaluation of Pretzel}

The sensory properties of the produced pretzels were evaluated for appearance, color, odor, taste, crispness, and mouthfeel by ten members of Food Technology Research Institute staff. Agriculture Research Center, according to Mc Williams (1997).

\subsection{Amino acids content and protein quality}

The amino acid contents of pretzel samples were determined using Automatic Amino Acid Analyzer (BIOCHROM 30, serial 103274), according to the method outlined in AOAC (2012). The quality of Pretzel' protein was determined using Protein Efficiency Ratio (PER) which was calculated according to the equation described by Alsmeyer et al. (1974) as follows:

$\mathrm{PER}=0.06320[\mathrm{X} 10]-0.1539$

Where X10 $=$ threonine + valine + methionine + isoleucine + leucine + phenylalanine + lysine +histidine + arginine + tyrosine. 
The biological value (B.V) was calculated according to Eggum et al. (1979) using the following equation:

B. $\mathrm{V} \%=39.55+8.89 \times$ lysine $(\mathrm{g} / 100 \mathrm{~g}$ protein $)$

2.6. Total phenols, total flavonoid contents and 2, 2- diphenyl-1-picrylhydrazyl (DPPH) activity

Total phenols were determined according to Singleton and Rossi (1965) using Folin-Ciocalteu reagent. Samples were measured at $765 \mathrm{~nm}$, and the concentration was expressed as milligrams of Gallic acid equivalents (GAE)/100g.

Total flavonoids was measured spectrophotometrically according to the method of Nasri et al., (2011) and concentration was expressed as $\mathrm{mg}$ quercetin/g.

The DPPH (2,2-diphenyl-1-picrylhydrazyl) radical scavenging activity of methanolic extracts was determined by using the method reported by Okonogi et al. (2007).

\subsection{Water activity $\left(\alpha_{\mathrm{w}}\right)$}

Water activity $\left(\alpha_{\mathrm{w}}\right)$ of different pretzel samples were measured with a Rotronic Hygro Lab EA10SCS (Switzerland) $a \mathrm{w}$ meter. The measurements were performed in triplicate.

\subsection{The hardness of pretzel}

The hardness of pretzel was conducted using a texture analyzer set (Ct3 Texture Analyzer Version 2.1, 10000 Gram unit, Brookfield, Engineering Laboratories, Inc. USA). Hardness was expressed in Newton $(\mathrm{N})$ and automatically recorded by computer software (TA-CT-PRO Software). The samples of $3.8 \mathrm{~cm}$ length and $0.7 \mathrm{~cm}$ diameter, were compressed to $50 \%$ of the original height using TA7 Probe, Fixture TA-JTPB, and test speed $2 \mathrm{~mm} / \mathrm{s}$. The hardness measurements were determined in triplicate.

\section{Statistical Analysis}

The data were analyzed using SPSS 16.0 software. Means and standard deviations were determined using descriptive statistics. Comparisons between samples were determined using analysis of one-way variance (ANOVA) and multiple range tests. Statistical significance was defined at $P \leq$ 0.05 .

\section{Results and Discussion}

\section{Chemical composition of raw materials}

The chemical composition of raw materials (wheat flour, barley flour, chickpea, sweet lupine, and turmeric powder) were shown in Table (2). Chemical composition of raw materials indicated that sweet lupine and chickpea powder contained higher amounts of protein, fat and crude fiber $(28.45$, $26.05 \% \& 7.53,8.08 \% \& 7.57,4.86 \%$ respectively) compared with other raw materials. On the other hand, wheat and barley flour had the highest contents of total carbohydrates (87.31 and $77.87 \%$ respectively) and the lowest contents of protein, fat, ash and crude fiber (9.41 and 11.04\%), (1.37 and $3.66 \%),(0.64$ and $3.08 \%)$ and $(1.27$ and $4.35 \%)$ respectively. These results are nearly following those reported by Hanan, (2013); Hussein et al., (2013); Eman Abd Rabou, (2017); El-Taib et al., (2018). Turmeric powder (as antioxidant and colorants agent) contained $10.63 \%, 4.89 \%, 9.62 \%, 6.13 \%$ and $68.73 \%$ for protein, fat, ash, crude fiber and total carbohydrates respectively.

Table 2: Chemical composition of raw materials (\%on dry weight basis)

\begin{tabular}{|c|c|c|c|c|c|}
\hline Samples & Protein & Fat & Ash & Crude fiber & $\begin{array}{c}\text { *Total } \\
\text { carbohydrates }\end{array}$ \\
\hline Wheat flour & $9.41 \pm 0.05$ & $1.37 \pm 0.03$ & $0.64 \pm 0.07$ & $1.27 \pm 0.10$ & $87.31 \pm 0.15$ \\
\hline Barley flour & $11.04 \pm 0.03$ & $3.66 \pm 0.11$ & $3.08 \pm 0.09$ & $4.35 \pm 0.06$ & $77.87 \pm 0.20$ \\
\hline Chickpea powder & $26.05 \pm 0.09$ & $8.08 \pm 0.07$ & $3.35 \pm 0.12$ & $4.86 \pm 0.03$ & $57.66 \pm 0.09$ \\
\hline Sweet lupine powder & $28.45 \pm 0.07$ & $7.53 \pm 0.03$ & $4.50 \pm 0.06$ & $7.57 \pm 0.12$ & $51.95 \pm 0.11$ \\
\hline Turmeric powder & $10.63 \pm 0.05$ & $4.89 \pm 0.08$ & $9.62 \pm 0.04$ & $6.13 \pm 0.09$ & $68.73 \pm 0.13$ \\
\hline
\end{tabular}

Values are means of three replicates \pm standard deviation.

*Total carbohydrates calculated by differences. 


\section{Sensory evaluation of pretzels}

Sensory evaluation is a unique discipline that makes use of experimental design and statistical analysis concepts to human senses, to evaluate consumer products (Kuenzel et al., 2011). Sensory characteristics of wheat and barley pretzel samples produced by chickpea or sweet lupine powder replacement were presented in Table (3). Results in Table (3) showed that samples replaced with chickpea powder at $40 \%$ or sweet lupin powder at $20 \%$ replacement in wheat and barley pretzel showed the highest scores for appearance, color, taste, mouthfeel, crispness, and overall acceptability. From the above results, it could be concluded that wheat and barley Pretzel samples made by replacing wheat flour or barley flour with $40 \%$ chickpea powder or $20 \%$ sweet lupine powder show a good accepted in different sensory characteristics.

Table 3: Effect of Chickpea and Sweet lupine powder on sensory parameter of wheat and barley pretzel

\begin{tabular}{|c|c|c|c|c|c|c|c|}
\hline Parameter & $\begin{array}{c}\text { Appearance } \\
10\end{array}$ & $\begin{array}{c}\text { Color } \\
10\end{array}$ & $\begin{array}{l}\text { Odor } \\
25\end{array}$ & $\begin{array}{l}\text { Taste } \\
25\end{array}$ & $\begin{array}{c}\text { Mouth feel } \\
15\end{array}$ & $\begin{array}{c}\text { Crispness } \\
15\end{array}$ & $\begin{array}{c}\text { Overall } \\
\text { acceptability } \\
100\end{array}$ \\
\hline \multicolumn{8}{|c|}{ Wheat Pretzel } \\
\hline Control(A) & $8.90 \pm 0.22^{c}$ & $9.00 \pm 0.50^{\mathbf{b}}$ & $21.40 \pm 0.75^{\mathrm{d}}$ & $20.05 \pm 0.97^{d}$ & $12.30 \pm 0.83^{d}$ & $12.50 \pm 0.67^{\mathrm{d}}$ & $84.15 \pm 1.90^{\mathrm{d}}$ \\
\hline 2 & $9.50 \pm 0.88^{\mathbf{b}}$ & $9.40 \pm 0.50^{\mathrm{a}}$ & $23.30 \pm 0.57^{\mathbf{b}}$ & $22.10 \pm 1.06^{\mathbf{c}}$ & $13.30 \pm 1.43^{\mathrm{c}}$ & $14.10 \pm 0.84^{\mathrm{c}}$ & $91.70 \pm 2.35^{\mathrm{c}}$ \\
\hline 3 & $9.80 \pm 0.22^{\mathrm{a}}$ & $9.64 \pm 0.99^{\mathrm{a}}$ & $23.70 \pm .89^{a}$ & $23.60 \pm 0.62^{\mathrm{a}}$ & $13.91 \pm 0.96^{\mathbf{a}}$ & $14.30 \pm 0.47^{\mathrm{a}}$ & $94.95 \pm 3.09^{\mathrm{a}}$ \\
\hline 4 & $9.80 \pm 0.42^{\mathrm{a}}$ & $9.64 \pm 0.66^{\mathrm{a}}$ & $23.08 \pm 1.03^{\mathrm{c}}$ & $23.25 \pm 0.90^{\mathbf{b}}$ & $13.70 \pm 1.08^{\mathbf{b}}$ & $14.27 \pm 0.83^{\mathbf{b}}$ & $93.74 \pm 2.83^{\mathbf{b}}$ \\
\hline 5 & $8.40 \pm 1.10^{\mathrm{d}}$ & $8.90 \pm 1.03^{c}$ & $20.80 \pm 1.17^{\mathrm{e}}$ & $19.60 \pm 1.10^{\mathrm{e}}$ & $11.30 \pm 0.84^{\mathrm{e}}$ & $11.20 \pm 0.97^{\mathrm{e}}$ & $80.20 \pm 3.68^{\mathrm{e}}$ \\
\hline \multicolumn{8}{|c|}{ Barley Pretzel } \\
\hline Control(B) & $8.00 \pm 0.53^{\mathrm{d}}$ & $7.90 \pm 0.64^{\mathrm{e}}$ & $19.10 \pm 1.22^{\mathrm{e}}$ & $21.30 \pm 0.73^{d}$ & $12.50 \pm 1.13^{\mathrm{d}}$ & $12.80 \pm 0.82^{\mathrm{c}}$ & $81.60 \pm 3.92^{\mathrm{d}}$ \\
\hline 7 & $9.26 \pm 0.87^{\mathfrak{c}}$ & $9.10 \pm 1.25^{\mathrm{c}}$ & $21.20 \pm 0.89^{\mathrm{c}}$ & $22.10 \pm 1.12^{\mathrm{c}}$ & $13.10 \pm 0.97^{\mathbf{c}}$ & $13.50 \pm 0.99^{\mathbf{b}}$ & $88.26 \pm 2.99^{c}$ \\
\hline 8 & $9.70 \pm 0.43^{\mathrm{a}}$ & $9.45 \pm 0.74^{\mathrm{a}}$ & $22.50 \pm 1.03^{\mathbf{b}}$ & $23.80 \pm 0.97^{\mathbf{a}}$ & $13.70 \pm 1.06^{\mathrm{a}}$ & $14.60 \pm 0.75^{\mathrm{a}}$ & $93.75 \pm 2.74^{\mathrm{a}}$ \\
\hline 9 & $9.50 \pm 1.02^{b}$ & $9.26 \pm 1.27^{\mathbf{b}}$ & $22.90 \pm 0.97^{\mathrm{a}}$ & $22.60 \pm 0.83^{\mathbf{b}}$ & $13.50 \pm 0.93^{\mathbf{b}}$ & $14.60 \pm 1.32^{\mathrm{a}}$ & $92.36 \pm 2.60^{\mathbf{b}}$ \\
\hline 10 & $7.70 \pm 0.66^{\mathrm{e}}$ & $8.30 \pm 1.02^{\mathrm{d}}$ & $19.30 \pm 1.16^{\mathrm{d}}$ & $20.85 \pm 1.18^{\mathrm{e}}$ & $11.50 \pm 0.62^{\mathrm{e}}$ & $11.20 \pm 1.07^{\mathrm{d}}$ & $78.85 \pm 4.68^{\mathrm{e}}$ \\
\hline
\end{tabular}

Values are means of ten replicates \pm standard deviation, number in the same column for wheat or barley pretzel followed by the same letter are not significantly different at 0.05 level.

\section{Chemical composition of pretzel}

The chemical composition of pretzel produced from wheat or barley flour (control A\&B) and samples with highly overall acceptability only ( $40 \%$ chickpea and $20 \%$ sweet lupine replacement) are presented in Table (4).Pretzels produced by replacing wheat or barley flour with $40 \%$ chickpea (No.3 $\& 8$ ) or $20 \%$ sweet lupine powder (No.4\&9) significantly increased in protein, fat, ash, and crude fiber comparing with control samples (A\&B). For wheat pretzel, sample No. (3) showed the highest content in protein, fat, ash, and crude fiber $(17.52,7.93,3.99$ and $3.84 \%$ respectively) followed by sample No. (4) which contain $14.69,6.16,3.23$ and $2.47 \%$ respectively. Also, for barley pretzel, sample No. (8) showed the highest content in protein and fat (18.25 and $9.20 \%$ respectively) followed by sample No. (9) which contain 15.98 and $8.70 \%$ respectively. While sample No. (9) was the highest content in ash and crude fiber followed by sample No. (8).

Table 4: Chemical composition of wheat and barley pretzels (\%on dry weight basis)

\begin{tabular}{ccccccc}
\hline $\begin{array}{c}\text { Items } \\
\text { Samples }\end{array}$ & Protein & Fat & Ash & Crude fiber & $\begin{array}{c}\text { *Total } \\
\text { carbohydrates }\end{array}$ & $\begin{array}{c}\text { Energy } \\
(\text { Kcal/100g) }\end{array}$ \\
\hline & & & \multicolumn{7}{c}{ Wheat Pretzel } \\
Control(A) & $11.09 \pm 0.15^{\mathbf{c}}$ & $5.25 \pm 0.05^{\mathbf{c}}$ & $2.33 \pm 0.03^{\mathbf{c}}$ & $1.39 \pm 0.07^{\mathbf{c}}$ & $79.94 \pm 0.27^{\mathbf{a}}$ & $411.37 \pm 0.29^{\mathbf{b}}$ \\
$\mathbf{3}$ & $17.52 \pm 0.11^{\mathbf{a}}$ & $7.93 \pm 0.04^{\mathbf{a}}$ & $3.99 \pm 0.01^{\mathbf{a}}$ & $3.84 \pm 0.09^{\mathbf{a}}$ & $66.72 \pm 0.21^{\mathbf{c}}$ & $408.33 \pm 0.25^{\mathbf{a}}$ \\
$\mathbf{4}$ & $14.69 \pm 0.09^{\mathbf{b}}$ & $6.16 \pm 0.07^{\mathbf{b}}$ & $3.23 \pm 0.09^{\mathbf{b}}$ & $2.47 \pm 0.06^{\mathbf{b}}$ & $73.45 \pm 0.29^{\mathbf{b}}$ & $408.00 \pm 0.19^{\mathbf{c}}$ \\
\hline & & \multicolumn{5}{c}{ Barley Pretzel } \\
Control(B) & $12.31 \pm 0.17^{\mathbf{c}}$ & $7.04 \pm 0.16^{\mathbf{c}}$ & $4.07 \pm 0.06^{\mathbf{c}}$ & $4.82 \pm 0.15^{\mathbf{c}}$ & $71.76 \pm 0.13^{\mathbf{a}}$ & $399.64 \pm 0.21^{\mathbf{b}}$ \\
$\mathbf{8}$ & $18.25 \pm 0.08^{\mathbf{a}}$ & $9.20 \pm 0.15^{\mathbf{a}}$ & $4.40 \pm 0.04^{\mathbf{b}}$ & $5.71 \pm 0.11^{\mathbf{b}}$ & $62.44 \pm 0.19^{\mathbf{c}}$ & $405.56 \pm 0.27^{\mathbf{a}}$ \\
$\mathbf{9}$ & $15.98 \pm 0.02^{\mathbf{b}}$ & $8.70 \pm 0.11^{\mathbf{b}}$ & $5.29 \pm 0.07^{\mathbf{a}}$ & $7.05 \pm 0.05^{\mathbf{a}}$ & $62.98 \pm 0.17^{\mathbf{b}}$ & $394.14 \pm 0.15^{\mathbf{c}}$ \\
\hline
\end{tabular}

Values are means of three replicates \pm standard deviation, number in the same column for wheat or barley pretzel followed by the same letter are not significantly different at 0.05 level.

*Total carbohydrates calculated by differences 
On the other hand, total carbohydrates significantly $(\mathrm{p}<0.05)$ decreased by replacing wheat or barley flour with chickpea or sweet lupine powder. Pretzel samples made by replacing wheat or barley flour with $40 \%$ chickpea powder had energy values 408.33 and $405.56 \mathrm{Kcal} / 100 \mathrm{~g}$ respectively while the least energy values were recorded for samples made by replacing wheat or barley flour with $20 \%$ sweet lupine powder 408.00 and $394.14 \mathrm{Kcal} / 100 \mathrm{~g}$ respectively.

\section{Minerals content}

Mineral contents of control Pretzels and samples with highly overall acceptability are presented in Table (5). The results were significantly different. Data revealed that all pretzel samples produced by replacing wheat or barley flour with chickpea powder or sweet lupine powder had higher contents of minerals compared to control samples. For wheat pretzels the highest values of magnesium, potassium, calcium, iron, phosphorus and zinc detected in pretzel made by replacing wheat flour with $40 \%$ chickpea powder $(82.92,656.35,77.02,7.79,94.77$ and $2.48 \mathrm{mg} / 100 \mathrm{~g}$ respectively).Regarding barley pretzel samples the highest values of magnesium, potassium and phosphorus noticed in pretzel made by replacing barley flour with $40 \%$ chickpea powder $(102.70,722.84$, and $87.64 \mathrm{mg} / 100 \mathrm{~g}$ respectively) while the highest values for sodium, calcium, iron, and zinc were observed in barley pretzel made by replacing barley flour with $20 \%$ sweet lupine powder $(528.84,107.28,9.93$ and 3.32 $\mathrm{mg} / 100 \mathrm{~g}$ respectively). Thus, it can be concluded that both chickpea powder and sweet lupine powder are a good source of minerals. These results agreed with Ferial and Esmat, (2011) who said that chickpeas are a rich source of minerals and with Jayasena et al. (2010) who showed that substitution of lupine flour from 10 to $50 \%$ in the instant noodles gradually increased the mineral contents.

From the same Table it could be observed that barley pretzel samples are characterized by the higher contents of magnesium, potassium, calcium, iron and zinc compared with wheat pretzel samples. This is due to the higher contents of magnesium, potassium, calcium, iron and zinc in their respective barley flour compared with wheat flour. These results are agreed with those obtained by ElTaib et al., (2018).

Table 5: Minerals content $(\mathrm{mg} / 100 \mathrm{~g})$ of wheat and barley pretzels

\begin{tabular}{cccccccc}
\hline $\begin{array}{c}\text { Mineral } \\
\text { Samples }\end{array}$ & Magnesium & Sodium & Potassium & Calcium & Iron & \multirow{2}{*}{ Phosphorus } & Zinc \\
\hline \multicolumn{7}{c}{ Wheat Pretzel } \\
Control(A) & $46.65 \pm 0.15^{\mathbf{c}}$ & $455.76 \pm 0.15^{\mathbf{c}}$ & $388.73 \pm 0.31^{\mathbf{c}}$ & $27.27 \pm 0.11^{\mathbf{c}}$ & $2.61 \pm 0.09^{\mathbf{c}}$ & $81.35 \pm 0.11^{\mathbf{c}}$ & $0.84 \pm 0.01^{\mathbf{c}}$ \\
$\mathbf{3}$ & $82.92 \pm 0.03^{\mathbf{a}}$ & $471.93 \pm 0.27^{\mathbf{b}}$ & $656.35 \pm 0.23^{\mathbf{a}}$ & $77.02 \pm 0.09^{\mathbf{a}}$ & $7.79 \pm 0.13^{\mathbf{a}}$ & $94.77 \pm 0.23^{\mathbf{a}}$ & $2.48 \pm 0.09^{\mathbf{a}}$ \\
$\mathbf{4}$ & $72.54 \pm 0.05^{\mathbf{b}}$ & $502.05 \pm 0.23^{\mathbf{a}}$ & $498.36 \pm 0.27^{\mathbf{b}}$ & $73.43 \pm 0.17^{\mathbf{b}}$ & $4.71 \pm 0.07^{\mathbf{b}}$ & $89.823 \pm 0.27^{\mathbf{b}}$ & $1.10 \pm 0.07^{\mathbf{b}}$ \\
\hline \multicolumn{7}{c}{ Barley Pretzel } \\
Control(B) & $67.38 \pm 0.01^{\mathbf{c}}$ & $411.10 \pm 0.31^{\mathbf{c}}$ & $452.30 \pm 0.11^{\mathbf{c}}$ & $58.05 \pm 0.01^{\mathbf{c}}$ & $7.20 \pm 0.03^{\mathbf{c}}$ & $73.41 \pm 0.25^{\mathbf{c}}$ & $1.89 \pm 0.01^{\mathbf{c}}$ \\
$\mathbf{8}$ & $102.70 \pm 0.13^{\mathbf{a}}$ & $467.82 \pm 0.21^{\mathbf{b}}$ & $722.84 \pm 0.32^{\mathbf{a}}$ & $99.76 \pm 0.05^{\mathbf{b}}$ & $9.45 \pm 0.21^{\mathbf{b}}$ & $87.64 \pm 0.21^{\mathbf{a}}$ & $2.61 \pm 0.03^{\mathbf{b}}$ \\
$\mathbf{9}$ & $96.63 \pm 0.07^{\mathbf{b}}$ & $528.84 \pm 0.14^{\mathbf{a}}$ & $630.15 \pm 0.21^{\mathbf{b}}$ & $107.28 \pm 0.03^{\mathbf{a}}$ & $9.93 \pm 0.05^{\mathbf{a}}$ & $77.38 \pm 0.32^{\mathbf{b}}$ & $3.32 \pm 0.11^{\mathbf{a}}$ \\
\hline
\end{tabular}

Values are means of three replicates \pm standard deviation, number in the same column for wheat or barley pretzel followed by the same letter are not significantly different at 0.05 level

\section{Amino acid composition}

Data presented in Table (6) show the amino acid composition of control pretzels and samples with highly overall acceptability. Essential amino acids (or indispensable amino acids) are the amino acids that cannot be synthesized by the human body and thus, they must be obtained from the diet (WHO/FAO/UNU, 2007). Results indicated that the sample made by replacing wheat flour with $40 \%$ chickpea powder had a higher Phenylalanine value $(6.05 \mathrm{~g} / 100 \mathrm{gm}$ protein) while the sample was made by replacing wheat flour with $20 \%$ sweet lupine powder had a higher tyrosine value (3.98 $\mathrm{g} / 100 \mathrm{gm}$ protein). On the other hand, sample made by replacing barley flour with $40 \%$ chickpea powder had higher value of threonine, lysine, and histidine $(3.79,4.33$, and $2.72 \mathrm{~g} / 100 \mathrm{gm}$ protein respectively) while the sample made by replacing barley flour with $20 \%$ sweet lupine powder had higher value isoleucine and leucine (4.35 and $7.73 \mathrm{~g} / 100 \mathrm{gm}$ protein respectively).

Lysine value as the major amino acid increased in all samples made with replacing wheat or barley flour with chickpea or sweet lupine powder expected in legume contained a higher amount of lysine than cereal this agree with those obtained by Rayas-Duarte et al. (1996); Mann and Truswell (2002); Hanaa et al. (2018). 
Generally, barley pretzel (control B) had higher total essential amino acids content followed by a pretzel with $20 \%$ sweet lupine powder. Meanwhile, pretzel sample made by replacing wheat flour with $40 \%$ chickpea had higher total essential amino acids content $(39.68 \mathrm{~g} / 100 \mathrm{~g}$ protein) compared with pretzel with $20 \%$ sweet lupine $(38.63 \mathrm{~g} / 100 \mathrm{~g}$ protein), then wheat pretzel (control A) had the lowest value ( $37.52 \mathrm{~g} / 100 \mathrm{~g}$ protein). For non-essential amino acids, barley pretzel made by replace $40 \%$ barley flour with chickpea powder had higher contents of aspartic, serine, glycine, alanine, and arginine values $(9.56,4.78,4.51,5.59$ and $7.85 \mathrm{~g} / 100 \mathrm{gm}$ protein, respectively). On the other hand, glutamic and proline were higher in wheat pretzel (control A) also, wheat pretzel samples had a higher content of total non-essential amino acids compared with barley pretzel samples.

However, all wheat or barley pretzel replacement samples had higher amount of total essential amino acids and all essential amino acids except lysine which covered only around $60.83 \%$ to $90.21 \%$ for child and $64.89 \%$ to $96.22 \%$ for adult when compared with the requirements for both child and adult.

Table 6: Amino acid composition (g/100 gm protein) of wheat and barley pretzels

\begin{tabular}{|c|c|c|c|c|c|c|c|c|}
\hline \multirow{3}{*}{$\begin{array}{l}\text { Samples } \\
\text { Amino acids }\end{array}$} & \multicolumn{3}{|c|}{ Wheat Pretzel } & \multicolumn{3}{|c|}{ Barley Pretzel } & \multirow{2}{*}{\multicolumn{2}{|c|}{$\begin{array}{c}\text { Ref. Pattern } \\
\text { FAO (2011) }\end{array}$}} \\
\hline & \multirow{2}{*}{ Control(A) } & \multirow{2}{*}{3} & \multirow{2}{*}{4} & \multirow{2}{*}{ Control (B) } & \multirow{2}{*}{8} & \multirow{2}{*}{9} & & \\
\hline & & & & & & & Child & Adult \\
\hline \multicolumn{9}{|c|}{ Essential amino acids } \\
\hline Thrionine & 3.00 & 3.38 & 3.41 & 3.60 & 3.79 & 3.57 & 2.50 & 2.30 \\
\hline Valine & 5.00 & 4.89 & 5.35 & 5.96 & 5.77 & 5.51 & 4.00 & 3.90 \\
\hline Isoleucine & 3.60 & 3.91 & 4.14 & 3.73 & 3.43 & 4.35 & 3.00 & 3.00 \\
\hline Leucine & 6.84 & 7.12 & 7.39 & 6.96 & 6.67 & 7.73 & 6.10 & 5.90 \\
\hline Pheneylalanine & 5.40 & 6.05 & 5.20 & 5.96 & 6.04 & 5.41 & ----- & ----- \\
\hline Tyrosine & 3.36 & 3.47 & 3.98 & 3.35 & 2.98 & 3.86 & ----- & ----- \\
\hline $\begin{array}{c}\text { Pheneylalanine } \\
\text { + Tyrosine }\end{array}$ & 8.76 & 9.52 & 9.18 & 9.31 & 9.02 & 9.27 & 4.10 & 3.80 \\
\hline Lysine & 2.40 & 3.74 & 2.92 & 2.98 & 4.33 & 3.96 & 4.80 & 4.50 \\
\hline Methionine & 2.40 & 2.14 & 1.46 & 2.61 & 1.98 & 1.45 & ----- & ----- \\
\hline Cystine & 3.36 & 2.40 & 2.35 & 4.22 & 2.62 & 2.80 & ----- & ----- \\
\hline $\begin{array}{l}\text { Methionine } \\
\text { + Cystine }\end{array}$ & 5.76 & 4.54 & 3.81 & 6.83 & 4.60 & 4.25 & 2.30 & 2.20 \\
\hline Histidine & 2.16 & 2.58 & 2.43 & 2.49 & 2.72 & 2.61 & 1.60 & 1.50 \\
\hline TEAA & 37.52 & 39.68 & 38.63 & 41.86 & 40.33 & 41.25 & 28.40 & 27.10 \\
\hline \multicolumn{9}{|c|}{ Non-essential amino acids } \\
\hline Aspartic & 4.56 & 8.72 & 7.55 & 7.33 & 9.56 & 8.79 & ----- & ----- \\
\hline Serine & 4.32 & 4.63 & 4.63 & 3.85 & 4.78 & 3.86 & ----- & ----- \\
\hline Glutamic & 31.31 & 23.75 & 27.68 & 22.49 & 20.56 & 21.74 & ----- & ----- \\
\hline Glycine & 4.20 & 3.91 & 4.14 & 4.35 & 4.51 & 4.25 & ----- & ----- \\
\hline Alanine & 3.72 & 4.45 & 3.82 & 4.85 & 5.59 & 4.35 & ----- & ----- \\
\hline Argnine & 3.84 & 7.21 & 6.57 & 5.34 & 7.85 & 7.83 & ----- & ----- \\
\hline Proline & 10.56 & 7.65 & 6.98 & 9.94 & 6.85 & 7.92 & ----- & ----- \\
\hline TNEAA & 62.51 & 60.32 & 61.37 & 58.15 & 59.70 & 58.74 & ----- & ----- \\
\hline
\end{tabular}

*Tryptophan was not determined.

** TEAA=Total essential amino acids, TNEAA=Total non-essential amino acids.

\section{Protein Quality of Pretzel}

Protein quality for pretzel samples are presented in Table (7). The parameters used in the evaluation of protein quality were Protein Efficiency Ratio (PER) and biological value (BV). Results showed that replacement wheat flour or barley flour with $40 \%$ chickpea or $20 \%$ sweet lupine resulted in an improvement in the PER ratio and BV of the pretzels.

Table 7: Protein quality of wheat and barley pretzels

\begin{tabular}{|c|c|c|c|c|c|c|}
\hline \multirow[b]{2}{*}{ Items } & \multicolumn{3}{|c|}{ Wheat Pretzel } & \multicolumn{3}{|c|}{ Barley Pretzel } \\
\hline & Control (A) & 3 & 4 & Control (B) & 8 & 9 \\
\hline Protein Efficiency Ratio (PER) & 2.25 & 2.66 & 2.55 & 2.56 & 2.73 & 2.77 \\
\hline Biological value\% (B.V) & 60.89 & 72.80 & 65.51 & 66.04 & 78.04 & 74.75 \\
\hline
\end{tabular}




\section{Total phenols, and flavonoids contents, and antioxidant activity of pretzels}

Total phenolic, flavonoids, and antioxidant activity of wheat, and barley pretzel samples with highly overall acceptability are shown in Table (8). Results in Table (8) showed that sample No. (3) and No. (8) contained a higher amount of total phenolic (2.19 and $2.83 \mathrm{mg}$ gallic acid /g respectively).

Also, the same trend in total flavonoids (1.99 and $2.66 \mathrm{mg}$ quercetin/g respectively). Meanwhile control (A) and control (B) showed the lowest content of total phenolic and total flavonoids $(1.43$ \& $2.01 \mathrm{mg}$ gallic acid $/ \mathrm{g})$ and $(0.78 \& 2.00 \mathrm{mg}$ quercetin $/ \mathrm{g})$ respectively. This means that chickpea or sweet lupine replacement causes an increase of total phenolic and total flavonoids (Ahmed, 2014).

From the same Table (8) antioxidant activity by DPPH\% assay showed that barley pretzel samples had the highest value of antioxidant activity $(42.34,51.16$, and $48.84 \%)$ for control (B), sample No. (8) and sample No. (9) respectively. While wheat Pretzel samples showed the lowest antioxidant activity $(21.17,33.61$, and $31.38 \%$ ) for control (A), sample No. (3), and sample No. (4) respectively. This was probably due to the increase antioxidant activity of barley flour compared with wheat flour (Zhao et al., 2008; Aludatt et al., 2012; El-Taib et al., 2018).

Also, from the above results, it could be concluded that sample No. (8) showed the highest antioxidant activity compared with other pretzel samples.

Table 8: Total phenolic, flavonoids and antioxidant activity of wheat and barley pretzels

\begin{tabular}{|c|c|c|c|}
\hline Samples & $\begin{array}{l}\text { Total phenolic as } \\
\text { mg gallic acid /g }\end{array}$ & $\begin{array}{c}\text { Total flavonoids as } \\
\text { mg quercetin /g }\end{array}$ & $\begin{array}{c}\text { Antioxidant activity } \\
\text { (Dpph\%) }\end{array}$ \\
\hline \multicolumn{4}{|c|}{ Wheat Pretzel } \\
\hline Control(A) & $1.43 \pm 0.03^{\mathrm{c}}$ & $0.78 \pm 0.06^{\mathbf{c}}$ & $21.17 \pm 0.05^{\mathbf{c}}$ \\
\hline 3 & $2.19 \pm 0.05^{\mathrm{a}}$ & $1.99 \pm 0.02^{\mathrm{a}}$ & $33.61 \pm 0.04^{\mathrm{a}}$ \\
\hline 4 & $2.13 \pm 0.07^{\mathrm{b}}$ & $1.77 \pm 0.04^{\mathrm{b}}$ & $31.38 \pm 0.06^{\mathbf{b}}$ \\
\hline \multicolumn{4}{|c|}{ Barley Pretzel } \\
\hline Control(B) & $2.01 \pm 0.01^{\mathrm{c}}$ & $2.00 \pm 0.03^{\mathrm{c}}$ & $42.34 \pm 0.01^{\mathbf{c}}$ \\
\hline 8 & $2.83 \pm 0.02^{\mathrm{a}}$ & $2.66 \pm 0.01^{\mathrm{a}}$ & $51.16 \pm 0.02^{\mathrm{a}}$ \\
\hline 9 & $2.09 \pm 0.04^{b}$ & $2.08 \pm 0.05^{\mathbf{b}}$ & $48.84 \pm 0.03^{\mathbf{b}}$ \\
\hline
\end{tabular}

Values are means of three replicates \pm standard deviation, number in the same column for wheat or barley pretzel followed by the same letter are not significantly different at 0.05 level.

\section{Moisture content, water activity $\left(\alpha_{w}\right)$ and hardness of wheat and barley pretzels}

Results in Table (9), showed that moisture content of the different pretzel samples was varied from $5.40 \%$ to $6.60 \%$ for wheat pretzel samples and from $5.60 \%$ to $6.80 \%$ for barley pretzel samples this probably due to the difference in water content of different pretzel samples.

Water activity $\left(\boldsymbol{\alpha}_{\mathbf{w}}\right)$ values of pretzel samples is the most commonly used criterion for safety and quality evaluations. The $\boldsymbol{\alpha}_{\mathbf{w}}$ were in a range from 0.40 to 0.43 for wheat pretzel samples, and from 0.42 to 0.45 for barley pretzel samples. The $\boldsymbol{\alpha}_{\mathbf{w}}$ of different pretzel samples was below the recommended water activity requirements for facilitates diverse microbial growth $-\boldsymbol{\alpha}_{\mathbf{w}}>0.80$ (Al-Eisa 2006).

Table 9: Moisture content, water activity $\left(\boldsymbol{\alpha}_{\mathrm{w}}\right)$ and hardness of wheat and barley pretzels

\begin{tabular}{|c|c|c|c|}
\hline Pretzel Samples & Moisture content (\%) & Water activity $\left(\alpha_{\mathrm{w}}\right)$ & Hardness $(\mathrm{N})$ \\
\hline \multicolumn{4}{|c|}{ Wheat Pretzel } \\
\hline Control(A) & $5.40 \pm 0.04^{\mathrm{c}}$ & $0.43 \pm 0.03^{\mathrm{a}}$ & $42.29 \pm 0.03^{b}$ \\
\hline 3 & $6.60 \pm 0.02^{\mathrm{a}}$ & $0.41 \pm 0.04^{\mathrm{a}}$ & $47.98 \pm 0.01^{\mathrm{a}}$ \\
\hline 4 & $5.60 \pm 0.03^{\mathbf{b}}$ & $0.40 \pm 0.02^{\mathrm{a}}$ & $28.52 \pm 0.02^{\mathrm{c}}$ \\
\hline \multicolumn{4}{|c|}{ Barley Pretzel } \\
\hline Control(B) & $5.60 \pm 0.03^{\mathrm{c}}$ & $0.42 \pm 0.02^{\mathrm{a}}$ & $17.55 \pm 0.02^{\mathrm{b}}$ \\
\hline 8 & $6.80 \pm 0.02^{\mathrm{a}}$ & $0.45 \pm 0.04^{\mathrm{a}}$ & $19.14 \pm 0.01^{\mathrm{a}}$ \\
\hline 9 & $6.40 \pm 0.04^{\mathbf{b}}$ & $0.43 \pm 0.03^{\mathrm{a}}$ & $16.75 \pm 0.01^{\mathrm{c}}$ \\
\hline
\end{tabular}

Values are means of three replicates \pm standard deviation, number in the same column for wheat or barley pretzel followed by the same letter are not significantly different at 0.05 level.

Hardness is the textural property that attracts more attention in the evaluation of baked goods, because of its close association with the human perception of freshness (Karaoğlu et al., 2009). Hardness values for different pretzels were illustrated in Table 9. The values of hardness for wheat 
pretzel samples ranked as follows: pretzel with $40 \%$ chickpea powder $>$ control sample $>$ pretzel with $20 \%$ sweet lupine powder. The same rank was observed for barley pretzel samples. Generally, wheat pretzel samples were more hardened than barley pretzel samples. This was probably due to the relative decreasing of gluten content in the dough weakened the strength of starch-protein crosslink, resulting in a non-swelled internal structure (Zhao et al., 2019).

\section{Conclusions}

From this study, it could be concluded that replacement of wheat flour and barley flour with $40 \%$ chickpea powder or $20 \%$ sweet lupine powder improved protein nutritional quality, minerals, total phenolic, flavonoids, and antioxidant activity of the resultant pretzels with acceptable sensory characteristic. All barley pretzel samples contained higher protein, ash, crude fiber, and other nutritional values such as protein quality, minerals, total phenolic, flavonoids, and antioxidant activity. Meanwhile, total carbohydrates and energy values were the lowest compared with wheat pretzel samples.

\section{References}

Ahmed, A.A., 2014. Influence of chemical properties of wheat-lupine flour blends on cake quality. American Journal of Food Science and Tech., 2 (2): 67-75.

Ahmed, K.R. and A.M.A. Hassan, 2019. Effect of planting method on barley productivity, water saving and nutrient use efficiency under El-Minia conditions. Middle East Journal of Agriculture Research, 8 (3):788-796.

Al-Eisa, H.A., 2006. The effect of using gluten free flours on the palatability, texture and water activity of white chocolate chip Macadamia Nut Cookies. Individual project written report. Food and nutrition, 453. C.F. Sharma and Riar (2020).

Alsmeyer, R.H., A.E. Cunningham, and M.L. Happich, 1974. Equations predict PER from amino acid analysis Journal of Food Technol., 28(7): 34-38.

Aludatt, M.H., R. Taha, E. Khalil, A. Inteaz, A.A. Mohamed, A. Ali, M. Nather, and M.A. Mohamad, 2012. Effects of barley flour and barley protein isolated on chemical. Functional, nutritional and biological properties of pita bread. Food Hydrocolloids, 28: 135-143.

AOAC, 2012. Official Method of Analysis Association of Official Analytical Chemists, $19^{\text {th }}$ Ed., Washington DC, USA.

Arab, E.A., I.M.F. Helmy, and G.F. Bareh, 2010. Nutritional evaluation and functional properties of chickpea (Cicer arietinum L.) flour and the improvement of spaghetti produced from its. J. Am. Sci., 6: 1055-1072.

Braga, M.E., P.F. Leal, J.E. Carvalho, and M.A.A. Meireles, 2003. Comparison of yield, composition, and antioxidant activity of turmeric (Curcuma longa L.) extracts obtained using various techniques. Journal of Agricultural Food and Chemistry, 51(22): 6604-6611.

Brennan, M.A., E. Derbyshire, B.K. Tiwari, and C.S. Brennan, 2013. Ready-to-eat snack products: The role of extrusion technology in developing consumer acceptable and nutritious snacks. Int. J. Food Sci. Tech., 48: 893-902.

Chardigny, J. M. and S. Walrand, 2016. Plant protein for food: opportunities and bottlenecks. OCL, DOI: $10.1051 / \mathrm{ocl} / 2016019$.

Clark, R. and S. Johnson, 2002. Sensory acceptability of foods with added lupin (Lupinus angustifolius) kernel fiber using pre-set criteria. J. Food Sci. 67: 356-362.

Day, L., 2013. Proteins from land plants-potential resources for human nutrition and food security. Trends Journal of Food Science and Technology, 32(1): 25-42.

Eggum B.O., E.F. Villegas, S.K. Vasal, 1979. Progress in protein quality of maize. Journal of the Science of Food and Agriculture, 30 (12):1148-1153.

El-Taib, H.I., I.R.S.A. Rizk, E.I. Yousif, and A.A. Hassan, 2018. Effect of barley flour on wheat bread quality. J. Agric. Sci., Ain Shams Univ., Cairo Special Issue, 26 (2A): 1109-1119.

Eman Abd Rabou, A.A., 2017. Effect of enriched gluten free biscuits with chickpea flour or kareish cheese on chemical, nutritional value, physical and sensory Properties. Alex. J. Agric. Sci., 62 (1): 93-101. 
FAO, 2011. Dietary protein quality evaluation in human nutrition. Report of FAO Expert Consultation. 31 March-2 April, Auckland, New Zealand.

Faris, M.E. and H.R. Takuri, 2002. Study of the effect of using different level takinah (Sesame butter) on the protein -digestibility- corrected amino acid score (PDCAAS) of chickpea dip, J. Sci. Food Agric., 83: 7-12.

Ferial, M.A. and A.A. Esmat, 2011. Physico-chemical properties of tempeh produced from chickpea seeds. Journal of American Science, 7(7):107-118.

Gómez, M., B. Oliete, C.M. Rosell, V. Pando, and E. Fernández, 2008. Studies on cake quality made of wheat-chickpea flour blends. LWT Food Sci. Tech., 41: 1701-1709.

Groff, E.T., 2001. Perfect pretzel production. In "Snack Foods Processing". E. W. Lusas and L. W. Rooney, eds. Technomic Publishing: Lancaster, PA., 369-383

Hanaa, H.M.E., F.M.A. Aly, A.S. Nadir, and H.G. El-Masry, 2018. Influence of chickpea, soy flour and protein isolate on pan bread quality and biological parameters in experimental rats. Middle East Journal of Applied, 8 (2): 307-324.

Hanan, F.A., 2013. Effect of fortification pan bread with lupine flour on the chemical, rheological and nutritional properties. J. Food and Dairy Sci., Mansoura Univ., 4 (3): 65-75.

Hefnawy, T.M.H., G.A. El-Shourbagy, and M.F. Ramadan, 2012. Impact of adding chickpea (Cicer arietinum L.) flour to wheat flour on the rheological properties of toast bread. Int. Food Res. J.19: 521-525.

Hussein, A.M.S., M.M. Kamil, N.A. Hegazy, and S.A.H. Abo EL-Nor, 2013. Effect of wheat flour supplemented with barely and/or corn flour on Balady bread quality. Pol. J. Food Nutr. Sci., 63(1): 11-18.

Jayasena, V., P.P.Y. Leung, and S.M. Nasar-Abbas, 2010. Effect of lupin flour substitution on the quality and sensory acceptability of instant noodles. Journal of Food Quality, 33, 709-727.

Jayaprakasha, G. K., R. Jaganmohan, and K. K. Sakariah, 2005. Chemistry and biological activities of C. longa. Trends in Food Science and Technol., 16 (12): 533-548.

Karaoğlu, M.M. and H.G. Kotancilar, 2009. Quality and textural behaviour of par-baked and rebaked cake during prolonged storage. Inter. J. Food Sci. Technol., 44(1): 93-99.

Kirleis, A.W., L.E. Sommers, and D.W. Nelson, 1984. Yield, heavy metal content and milling and baking properties of soft red winter wheat grown on soils amended with sewage sludge. Cereal Chem., 61(6): 518-522.

Kuenzel, J., E.H. Zandstra, W. El Deredy, I. Blanchette, and A. Thomas, 2011. Expecting yoghurt drinks to taste sweet or pleasant increases liking. Appetite 56(1): 122-127.

Lim, H.S., S.H. Park, K. Ghafoor, S.Y. Hwang, and J.Y. Park, 2011. Quality and antioxidant properties of bread containing turmeric (Curcuma longa L.) cultivated in South Korea. Food Chemistry, 124(4):1577-1582.

Loza, A. and E. Lampart-Szczapa, 2008. Allergenicity of lupine proteins - a review. Polish Journal of Food and Nutrition Sciences, 58: 283-287.

Makri, E., E. Papalamprou, and G. Doxastalis, 2005. Study of functional properties of seed storage proteins from indigenous European legume crops (lupin, pea, broad bean) in admixture with polysaccharides. Food Hydrocolloids, 19(3):583- 594.

Mann, J. and A. Truswell, 2002. "Essential of Human Nutrition". $2^{\text {nd }}$ Ed. published by Oxford University Press, New York, NY.

Mansour, M.I., 2007. Physical, Chemical and Biological on bread fortified by some legumes flour. M.Sc. Thesis, Faculty of Agriculture, El Fayoum University, Egypt.

Mc Williams, M., 1997. Sensory evaluation In. "Foods experimental perspectives". $3^{\text {rd }}$ ed. Merrillan Imprint. of Prentice Hall, Upper Saddle Rever, New Jersey, 33-67.

Narwal, S., D. Kumar, S. Sheoran, R.P.S. Verma and R.K. Gupta, 2017. Hulless barley as a promising source to improve the nutritional quality of wheat products. J. Food Sci. Technol., DOI 10.1007/s13197-017-2669-6.

Nasri, N., N. Tlili, W. Elfalleh, E. Cherif, A. Ferchichi , A. Khaldi, and S. Triki, 2011. Chemical compounds from Phoenician juniper berries (Juniperus phoenicea). Natural Product Research, 25(18):1733-1742. 
Okonogi, S., C. Duangrat, S. Anuchapreeda, S. Tachakittirungrod, and S. Chowwanapoonpohn, 2007.Comparison of antioxidant capacities and cytotoxicities of certain fruit peels. Food Chemistry, 103(3): 839-846.

Olatunde-Farombi, E., S. Sangeefc, T.F.N. Hye-Kyung, K. Sung-Hoon, and S. Young-Joon, 2008. Curcumin attenuates dimethyl-nitroseamine-induced liver injury in rats through Nrf2mediated induction of heme oxygenase-1. Food and Chemical Toxicology, 46 (4): 12791287.

Oliveira, L.C., C.M. Rosell, and C.J. Steel, 2015. Effect of the addition of whole-grain wheat flour and of extrusion process parameters on dietary fiber content, starch transformation and mechanical properties of a ready-to-eat breakfast cereal. Int. J. Food Sci. Technol., 50: $1504-1514$.

Ötles, S., and Ö. Cagindi, 2006. Cereal based functional foods and nutraceuticals. ACTA Scientiarum Polonorum Technologia Alimentaria, 5(1): 107-112.

Rayas-Duarte, P., C.M. Mock, and L.D. Satterlee, 1996. Quality of spaghetti containing buckwheat, amaranth, and lupin flours. Cereal Chem., 73: 381-387.

Sabanis, D. and C. Tzia, 2009. Effect of rice, corn and soy flour addition on characteristics of bread produced from different wheat cultivars. J. of Food Bioprocess Technol., 2 (1):68-79.

Seetharaman, K., N. Yao, and M.K. Rout, 2004. Role of water in pretzel dough development and final product quality, Cereal Chem., 181(3): 336-340.

Sekhon, K. S., 2014. Influence of defatted soy flour addition on the quality and stability of pretzel type product. J. Food Sci. Technol., 51 (3): 571-576.

Singleton, V.L., and J.A. Rossi, 1965. Colorimetry of total phenolics with phosphomolybdicphosphotungstic acid reagents. Am. J. Enol Vitic., 16:144-158.

Shahine-Fatma, I., A.M. Amer-Thanaa, and M.M. Dowidar-Mona, 2013. Preparation and evaluation healthy filling pie by using cheese and some vegetables. Journal of Agriculture Research, $91(1): 43-66$.

Sharma, S. and C.S. Riar, 2020. Effect of storage period and packaging materials on textural, phenolic, antioxidant properties of cookies made from raw and germinated minor millet blends flour. Annals. Food Science and Technol., 21 (1): 74-85.

Singh, G., I.P.S. Kapoor, P. Singh, C.S.D. Helnani, M.P.D. Lampasona, and C.A.N. Catalan, 2010. Comparative study of chemical composition and antioxidant activity of fresh and dry rhizomes of turmeric (Curcuma longa Linn.). Food Chemical Toxicology, 48(4): 10261031.

Struck, S., D. Jaros, S. Brennan, and H. Rohm, 2014. Sugar replacement in sweetened bakery goods. Int. J. Food Sci. Technol., 49: 1963-1976.

WHO/FAO/UNU, 2007. Protein and amino acid requirements in human nutrition. Report of a Joint WHO/FAO/UNU Expert consultation. WHO Press, World Health Organization, Avenue Appia, Geneva, Switzerland.

Yadav, R.B., B.S. Yadav, and N. Dhull, 2012. Effect of incorporation of plantain and chickpea flours on the quality characteristics of biscuits. J. Food Sci. Technol., 49: 207-213.

Zafar, T.A., F. Al-Hassawi, F. Al-Khulaifi, G. Al-Rayyes, C. Waslien, and F.G. Human, 2013. Organoleptic and glycemic properties of chickpea-wheat composite breads. J. Food Sci. Technol., Doi 10.1007/s 13197-013-1192-7.

Zhao, H., W. Fan, J. Dong, J. Lu, J. Chen, L. Shan, Y. Lin, and W. Baokong, 2008. Evaluation of antioxidant activities and total phenolic contents of typical malting barley varieties. Food Chem., 107 (1): 296-304.

Zhao, J., X. Liu, X. Bai, and F. Wang, 2019. Production of biscuits by substitution with different ratios of yellow pea flour. Grain \& Oil Science and Technol., 2: 91-96. 